\title{
THE MASSAGE APPROACH OF AVICENNA IN THE CANON OF MEDICINE
}

\author{
AVICENIN PRISTUP MASAŽI U NJEGOVU \\ DJELU KANON MEDICINE
}

\author{
Murat Çetkin*, İlhan Bahşi**, Mustafa Orhan**
}

\begin{abstract}
SUMMARY
Massage is the manipulation of the body tissues by using techniques, such as rubbing, kneading, pressing, and rolling to sustain a state of health and wellness. Massage is one of the oldest and most natural healing applications in human history. Avicenna (980-1037) gained a very important position in the medical world with his most important work, the Canon of Medicine, known as the holy book of medicine in the Western world. Different types of massage were defined in the book. These were hard friction that braces the body, soft friction that relaxes the body, repeated friction that reduces the amount of fat in the body, moderately hard friction that improves the body, rough friction that leads the blood to the surface rapidly, gentle friction that increases blood flow in the application area, preparatory friction that prepares the body before exercise, and restorative friction that is applied after exercise which alleviates exhaustion. It may be seen that Avicenna, whose work shows influence of Greek and Roman physicians, was heavily influenced by Hippocrates and Galen. It is seen that the massage techniques and effect mechanisms defined by Avicenna about a thousand years ago have contributed a lot to the developments in massage through the historical process.
\end{abstract}

Keywords: Avicenna, Canon of Medicine, massage

* Department of Anatomy, Faculty of Medicine, İstanbul Medeniyet University, İstanbul, Turkey.

** Department of Anatomy, Faculty of Medicine, Gaziantep University, Gaziantep, Turkey.

Correspondence Address: Murat Çetkin, Department of Anatomy, Faculty of Medicine, İstanbul Medeniyet University, Dumlupınar street, D100 No:98, 34000, Kadıköy/ İstanbul/Turkey, İstanbul, Turkey. E-mail: muratcetkin@hotmail.com. 


\section{INTRODUCTION: A BRIEF HISTORY OF MASSAGE}

Massage is the manipulation of the body tissues by using techniques, such as rubbing, kneading, pressing, and rolling to sustain a state of health and wellness. The origin of the word massage reaches back to roots in different languages like Greek (massein- to knead), Arabic (mass-to touch) and Latin (manus-hand). ${ }^{1}$ Massage is one of the oldest and most natural healing techniques in human history. The history of massage reaches back to ancient times. Ancient civilizations used massage not only to alleviate pain, but also to improve their physical appearances and state of wellness. The earliest written knowledge regarding massage, which is one of the oldest healing procedures of humanity, may be found in the Chinese resources. The Chinese utilized massage to treat illnesses and sustain health about 5000 years ago. The Cong Fou of Tao-Tse, which is one of the oldest books in Chinese culture, describes the effects of exercise and massage on treating illnesses and sustaining health. The history of massage on the Indian peninsula reaches back to 3000 s BCE. Massage techniques are described in the piece named the Ayur-Veda written in Hindi in I8oos BCE. ${ }^{2,3}$ Reflexology, a type of massage applied to the foot and hand corresponding zones of body, has been dated as far back as more than 4000 years ago in Ancient Egypt. ${ }^{4}$ In Ancient Assyria and Babylonia, effected organs were massaged and rubbed with oil and ointments by "asu" (physician). ${ }^{5}$ The massage can be also seen in Shamanism, which is the most ancient form of spiritual practices of humanity, and has a healing practice in cross-cultural manner. Shamanic healing practices evoke emotions and healing through physical treatments, including massage. ${ }^{6,7}$ A significant physician of the Ancient Greek civilization, Asclepius (I200 $\mathrm{BCE})$, used mild amounts of exercise combined with massage to sustain

1 Cafarelli E, Flint F. (1992) 'The role of massage in preparation for and recovery from exercise', Sports Medicine, 14, 1-9.

2 Beck MF. (2010), Theory and practice of therapeutic massage. New York: Cengage Learning, 5,781 .

3 O'Keefe A. (2006) The official guide to body massage. London: Thomson Learning, 15.

4 Beck MF. (2010), Theory and practice of therapeutic massage. New York: Cengage Learning, $5,781$.

5 Paulissian R. (1993) 'Dental Care in Ancient Assyria and Babylonia', Journal of Assyrian Academic Studies, 3-51.

6 Winkelman M. (2002) 'Shamanism as Neurotheology and Evolutionary Psychology', American Behavioral Scientist, 45, 1873-1885.

7 Steinhorn DM, Din J, Johnson A. (2017) 'Healing, spirituality and integrative medicine' Annals of Palliative Medicine, 6, 237-247. 
well-being, treat illnesses and alleviate pain. ${ }^{8,9}$ In the famous work of Homer, Odyssey, it was said that massage was used to treat people injured in wars. ${ }^{10}$ Hippocrates (460-370 BCE), known as the father of medicine, mentioned the effects of massage by saying "hard rubbing binds, much rubbing causes parts to waste, and moderate rubbing makes them grow." Hippocrates used the word "anatripsis", which means stroking only upward to the heart (not downward). He stated that stroking should be hard, moderate, or mild based on the state of the tissue and the desired effect. He reported the need to rub the shoulder area after fixing a dislocation. ${ }^{11}$ The Romans learned the therapeutic effects of massage from the Greeks and used it to get rid of tenseness and pain in muscles. ${ }^{12,13}$ Celsus ( $\left.42 \mathrm{BCE}-37 \mathrm{AD}\right)$ stated that rubbing the head area alleviates headaches and rubbing extremities strengthens the muscles and improves their function in paralysis. ${ }^{14}$ Galen (I29-2IO AD) included application of massage in addition to exercise and walking among factors that affect well-being and illness states. ${ }^{15}$ According to Galen, it leads to removal of the excess materials (agents) in the body. ${ }^{16}$ Written works in Europe regarding massage and scientific developments were revitalized after the Middle Ages with the Renaissance (I450 - I600 AD). Physicians used massage in treatment in the r6th century. French physician Ambroise Paré (I517 - 1590), who was one of the pioneers of modern surgery, reported the positive effects of massage in the process of recovery. He described the movements used in massage as gentle, medium and vigorous frictions. ${ }^{17,18}$ Hieronymus Mercurialis (1530 - 1606), a professor of medicine, included the positive effects of massage applied in integration with other treatments on the body

8 Beck MF. (2010) Theory and practice of therapeutic massage. New York: Cengage Learning, 5, 781.

9 Ahmed K, Jahan N, Aslam M, Kausar H, Khalid M, Ali H Dalak. (2014) 'Massage in Unani medicine: a review' International Journal of Advanced Ayurveda Yoga Unani Siddha Homeopathy, 3, 162-174.

10 O'Keefe A. (2006) The official guide to body massage. London: Thomson Learning, 15.

11 Calvert RN. (2002) The history of massage. An illustrated survey from around the world. Rochester, VT: Healing arts press, 46.

12 Beck MF. (2010), Theory and practice of therapeutic massage. New York: Cengage Learning, $5,781$.

13 O'Keefe A. (2006) The official guide to body massage. London: Thomson Learning, 15.

14 Beck MF. (2010), Theory and practice of therapeutic massage. New York: Cengage Learning, $5,781$.

15 Calvert RN. (2002) The history of massage. An illustrated survey from around the world. Rochester, VT: Healing arts press, 46.

16 Prioreschi P. (1998) A history of medicine: Roman medicine. Omaha: Horatius Press, 449.

17 Beck MF. (2010), Theory and practice of therapeutic massage. New York: Cengage Learning, 5,781 .

18 Ryan AJ. (1984) 'Exercise and health: lessons from the past' In: Eckert HM, Montoye HJ, Eds, Exercise and health: the academy papers, Minnesota: Human kinetics publishers, 3-13. 
and the mind in his work named De Arte Gymnastica in $1569 .{ }^{19}$ The Swedish physiologist Per Henrik Ling (I776 - I839), known as the father of modern massage and physiotherapy, systematized the movements used in medical gymnastics by utilizing the developments in physiology. Movements were categorized as active, duplicate and passive in Ling's protocol. Among the passive movements, massage was used as a treatment tool applied by a therapist. Ling's treatment system was later used in the rest of Europe and Russia as Swedish movements or movement treatment. The terminology of massage in the modern sense was defined by Dr. Johan Mezger (I839- I909), who used massage as a scientific element in treatment of illnesses. With Mezger's effort, massage has gained popularity as scientific medical treatment and a significant place in physiotherapy and rehabilitation..$^{20,21,22}$

\section{Massage in the Canon of medicine}

Avicenna (980 - I037, Fig. I) gained a very important position in the medical world with his most important work the Canon of Medicine, known as the holy book of medicine in the Western world. The Canon of Medicine is a five-volume work which had been used as a textbook in the East until the 17 th century. ${ }^{23}$ Avicenna systematized the dispersed medical information accumulated from Ancient Greece until that period by synthesizing them, and then updated them with his personal observations. The general influence of Galen's and Hippocrates' teachings may be seen in the work of Avicenna.. 24

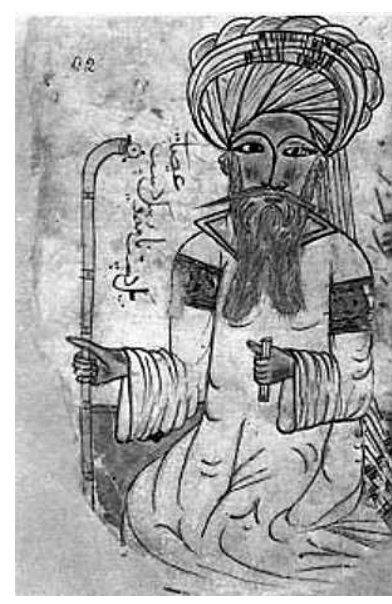

Figure I. A drawing of Avicenna from I27I.

The massage is described in detail in a separate massage chapter in the Canon of Medicine, in the "Preservation of Health" section in volume one.

19 Beck MF. (2010), Theory and practice of therapeutic massage. New York: Cengage Learning, 5,781 .

20 Ibid.

21 Moyer CA, Rounds J, Hannum JW. (2004) 'A meta-analysis of massage therapy research', Psychological Bulletin, 130, 3-18.

22 Chikly BJ. (2005) 'Manual techniques addressing the lymphatic system: origins and development', The Journal of the American Osteopathic Association, 105,457-464.

23 Moosavi J. (2009) 'The place of Avicenna in the history of medicine', Avicenna Journal of Medical Biotechnology, 1, 3-8.

24 Bayat AH. (2010) Tip tarihi, İstanbul: Merkezefendi Geleneksel Tip Derneği, 224. 
There are information about effects and technics in this section. ${ }^{25,26}$ In other chapters, the information about effects of massage and timing can also be seen.

\section{Types of MASSAge}

The eight types of massage were explained in the Canon of Medicine. The enumeration with letters was performed for all eight types in English translation. ${ }^{27}$ However, in Turkish translation, only four massage types were numbered and others were explained without enumeration. ${ }^{28}$ The Canon of Medicine includes information on the effect mechanism and technique of each method of massage. The massage types and explanations in the Canon of Medicine are listed in order below. ${ }^{29,30}$

- Hard friction: Stretches, contracts and braces the body.

- Soft friction: It has a relaxing effect on the body.

- Repeated friction: It reduces the amount of fat in the body. This type is performed with long-term friction.

- Moderately hard friction: Improves the mass of organs.

- Rough friction: It leads the blood to the surface rapidly. Rough friction is made with a rough towel.

- Gentle friction: Increases the blood flow in the application area. The purpose of this friction is to modify the tone of the body.

- Preparatory friction: Prepares the body before exercise. It begins with gentle friction, and then becomes forceful just before exercise.

- Restorative friction: The restorative massage was explained in more detail than other massage types in this chapter. Technical information regarding restorative massage was also provided in this section. It is stated that the restorative massage relaxes the body. It is applied after exercise and disperses the exhausting matters from muscles. The healing effect of massage is described as removal of unnecessary substances from the body by the reduction of tense areas in the area of application. Additionally, it was reported that massage stimulates natural temperatures, widens the pores, and also relaxes the body. This

Kâhya E. (2014) El-Kanun Fi't-Tıbb, Ankara: Atatürk Kültür Merkezi Yayınları, 302-303.

26 Gruner OC, Shah MH, Crook JR. (1973) The Canon of Medicine (al Qānūn Fì'l-t.ibb), New York: Great Books of the Islamic World Inc, AMP Press, 389-391.

27 Ibid.

28 Kâhya E. (2014) El-Kanun Fi't-Tıbb, Ankara: Atatürk Kültür Merkezi Yayınları, 302-303.

29 Ibid.

30 Gruner OC, Shah MH, Crook JR. (1973) The Canon of Medicine (al Qānūn Fì'l-t.ibb), New York: Great Books of the Islamic World Inc, AMP Press, 389-391. 
friction type could negatively affect the growth of a child, while it is less harmful for adults.

This chapter also discussed the relationship between restorative massage and exercise. It was reported that, based on the time of exercise, restorative massage could be applied during the exercise. It was stated that restorative massage is applied at the end of the exercise, starting with hard pressure using oil, and applied in decreasing hardness until the tenseness in the tissues disappear. The rubbed limb is being stretched at the end of the massage. This stretch helps to disperse the exhausting matters. The massaged area is covered with a towel. It was recommended that massage should apply more than one person. In the text, it was argued that the person has to release their abdominal muscles while holding their breath. The abdominal muscles are contracted again after the treatment. This way, the bowels are stimulated to some extent.

Except for the specific section about massage, different chapters of the book include information on the specialized effects of massage. In the "exercise" section of the book, it is stated that the massage before exercise revives the innate heat and expands the holes. The massage is beneficial for decreasing pain due to exercise. The massage should be made with a rough towel at the beginning, then sweet oil should be applied with a palm of a hand before exercise. ${ }^{31,32,33}$ In the "treatment of following exercise" section, the massage with oil is advised for ulcer, tensness, inflammation, and lassitude. In the "cold baths" chapter, it is stated that the massage is combined with cold bath. Before cold baths, the massage should be more forceful and longer. It was reported that massage applied to the chest gently increased mother's milk. The gums of children, who have erupted teeth, are massaged with oil. In the period of edema that occurs after the exercise, this massage should be carried out from the distal to the proximal. The massage should be moderate in the elderly, and it should not involve weak and painful parts of the body. If the massage is repeated in the same day for the elderly, it shall be carried out with a rough towel or bare hands. Massage that is carried out with oil

\footnotetext{
Kâhya E. (2014) El-Kanun Fi't-Tıbb, Ankara: Atatürk Kültür Merkezi Yayınları, 302-303. Gruner OC, Shah MH, Crook JR. (1973) The Canon of Medicine (al Qānūn Fì'l-t.ibb), New York: Great Books of the Islamic World Inc, AMP Press, 389-391.

33 Çetkin M, Bahsi I, Orhan M. (2016) 'Evaluation of exercise in Canon of Medicine', Archives of Iranian Medicine, 19, 743-746.
} 
increases the activity of laxatives. It was recommended to massage the upper part of the stomach after vomiting. ${ }^{44,35}$

While massage has been one of the regimental therapies that are used in Greek medicine for protecting health, it has been used prevalently for protective and therapeutic purposes. ${ }^{36,37}$ Hippocrates reported that the humidity, heat and dryness of the body could be restored after disruption of it following a pathological process. Hippocrates stated that massage tightened the joint that is loosened, and relaxed a joint that is rigid or tight. Hippocrates argued that the body parts could be solidified or relaxed by massaging. In Hippocrates's book "Officina del medico" (the workshop of the doctor), there is also explanations about timing and frequency of massage. ${ }^{38} \mathrm{Herbal}$ oil that is used in massages in Ancient Greece has a significant therapeutic place. ${ }^{39,40}$ In his work "Gymnastics-Epistolai", Philostratus claimed that massage applied with olive oil would make athletes feel good, protect them from illness and make them feel young. ${ }^{41}$ Galen argued that morbid materials are taken away from the body by massaging in 'Hygiene'. ${ }^{42,43}$ He stated that the massage begins with slow friction, and then the strength should increase. According to Galen's massage theory, the effect mechanism is depending on the direction of massage maneuver (e.g. the round massage hardens,

34 Kâhya E. (2014) El-Kanun Fi’t-Tibb, Ankara: Atatürk Kültür Merkezi Yayınları, 302-303.

35 Gruner OC, Shah MH, Crook JR. (1973) The Canon of Medicine (al Qānūn Fì'l-t.ibb), New York: Great Books of the Islamic World Inc, AMP Press, 389-391.

36 Ahmed K, Jahan N, Aslam M, Kausar H, Khalid M, Ali H Dalak. (2014) 'Massage in Unani medicine: a review' International Journal of Advanced Ayurveda Yoga Unani Siddha Homeopathy, 3, 162-174.

37 Ansari S, Khan QA, Anjum R, Siddiqui A, Sultana K. (2017) 'Fundamentals of Unani system of medicine-A review', European Journal of Biomedical and Pharmaceutical Science, 4, 219-223.

38 Iorio S, Marinozzi S, Gazzaniga V. (2018) 'Healing bodies: the ancient origins of massages and Roman practices', Medicana Historica, 2, 58-62.

39 Ibid.

40 Gode RK. (1955) 'History of the practice of massage in Ancient and Medieval India between c. B.C. 1000 and A.D. 1900', Annals of the Bhandarkar Oriental Research Institute, 36, $85-113$.

41 Nomikos NN, Nomikos GN, Kores DS. (2010) 'The use of deep friction massage with olive oil as a means of prevention and treatment of sports injuries in ancient times', Archives of Medical Science, 6, 642-645.

42 Ahmed K, Jahan N, Aslam M, Kausar H, Khalid M, Ali H Dalak. (2014) 'Massage in Unani medicine: a review' International Journal of Advanced Ayurveda Yoga Unani Siddha Homeopathy, 3, 162-174.

43 Iorio S, Marinozzi S, Gazzaniga V. (2018) 'Healing bodies: the ancient origins of massages and Roman practices', Medicana Historica, 2, 58-62. 
contracts and tightens the tissues, while the straight massage relaxes, softens and loosens the body). ${ }^{4}$

There are similarities between the Ancient Greek Medicine and the Canon of Medicine. Avicenna also combined massaging with exercise and used different herbal oils in this process. He also mentioned the stretching and relaxing effects of massage. The physiological effect mechanism that he explained as evacuation of unnecessary substances from the body also corresponds to the explanations in Ancient Greek medicine.

While parts of the body are exposed to short-term strong forces based on the type of exercise, they may be exposed to long-term lesser forces repeatedly. In our time, the massage is used prevalently in eliminating the negative effects of exercise on the body ${ }^{45}$ The effects of massage have been based on its biomechanical, physiological, neurological and psychological mechanisms. ${ }^{46}$ There is still a debate on the effects of massage on muscle stiffness. There are studies in the literature that quantitatively demonstrated that massaging reduced muscle stiffness ${ }^{47}$ or did not change it..$^{48,49}$ As seen in the case of muscle stiffness, the effect of massage on the blood flow and the blood lactation levels is also speculative at the present time. ${ }^{50,51,52}$ This is why there is a need for more studies focusing on the effect mechanisms of massage. In Avicenna's statements, there is knowledge that has been accepted as the truth nowadays. Avicenna's reports correspond to current knowledge in that the mas-

44 Ibid.

45 Cafarelli E, Flint F. (1992) 'The role of massage in preparation for and recovery from exercise', Sports Medicine, 14, 1-9.

46 Weerapong P, Hume PA, Kolt GS. (2005) 'The mechanisms of massage and effects on performance, muscle recovery and injury prevention", Sports Medicine, 35, 235-256.

47 Crommert ME, Lacourpaille L, Heales LJ, Tucker K, Hug F. (2015) 'Muscle induces an immediate, albeit short-term, reduction in muscle stiffness', Scandinavian Journal of Medicine and Sports, 25, 490-496.

48 Thomson D, Gupta A, Arundell J, Crosbie J. (2015) 'Deep soft tissue massage applied to healthy calf muscle has no effect on passive mechanical properties: a randomized single-blind, cross-over study', BMC Sport Science, Medicine and Rehabilitation, 7, 21.

49 Kong PW, Chua YH, Kawabata M, Burns SF, Cai C. (2018) 'Effect of post-exercise massage on passive muscle stiffness measured using myotonometry-A double-blind study' Journal of Sports Science and Medicine, 17, 599-606.

50 Mori H, Ohsawa H, Tanaka TH, Taniwaki E, Leisman G, Nishijo K. (2004) 'Effect of massage on blood flow and muscle fatique following isometric lumbar exercise', Medical Science Monitor, 10, 173-178.

51 Hinds T, Mcewan I, Perkes J, Dawson E, Ball D, George K. (2004) 'Effects of massage on limb and skin blood flow after quadriceps exercise', Medicine and Science in Sports and Exercise, 36, 1308-1313.

52 Tiidus PM, Shoemaker K. (1995) 'Effleurage massage, muscle blood flow and long-term post-exercise strength recovery', International Journal of Sports Medicine, 16, 478-483. 
sage "increases blood flow in the area of application", "has a relaxing effect" and "helps elimination of unnecessary substances". In addition, similar to Avicenna's definitions of preparatory friction and restorative friction, massage is applied before and after exercise today. Massage applications are provided to athletes today before and after sports competitions in compliance with Avicenna. The terminology today in the massage maneuvers shows similarities, although it differs from those proposed by Avicenna. However, it was stated that a person receiving a wrong kind of massage should hold their breath.

\section{Conclusion}

Today, various massage techniques are used as a complementary therapy with therapeutic goals in medical centers. It may be seen that Avicenna, whose work shows influence of Greek and Roman physicians, was heavily influenced by Hippocrates and Galen. Galen's usage of massage in combination with exercise and definition of it as a factor that removes excess material from the body are examples of this interaction. 


\section{REFERENCES}

1. Ahmed K, Jahan N, Aslam M, Kausar H, Khalid M, Ali H Dalak. (2014) 'Massage in Unani medicine: a review' International Journal of Advanced Ayurveda Yoga Unani Siddha Homeopathy, 3, 162-174.

2. Ansari S, Khan QA, Anjum R, Siddiqui A, Sultana K. (2017) 'Fundamentals of Unani system of medicine-A review', European Journal of Biomedical and Pharmaceutical Science, 4, 219-223.

3. Bayat AH. (2010) Tip tarihi, İstanbul: Merkezefendi Geleneksel Tip Derneği, 224. Kâhya E. (2014) El-Kanun Fi't-Tıbb, Ankara: Atatürk Kültür Merkezi Yayınları, 302-303.Gruner OC, Shah MH, Crook JR. (1973) The Canon of Medicine (al Qānūn Fìl-t.ibb), New York: Great Books of the Islamic World Inc, AMP Press, 389-391.

4. Beck MF. (2010) Theory and practice of therapeutic massage. New York: Cengage Learning, 5, 781.

5. Cafarelli E, Flint F. (1992) 'The role of massage in preparation for and recovery from exercise', Sports Medicine, 14, 1-9.

6. Calvert RN. (2002) The history of massage. An illustrated survey from around the world. Rochester, VT: Healing arts press, 46.

7. Çetkin M, Bahsi I, Orhan M. (2016) 'Evaluation of exercise in Canon of Medicine', Archives of Iranian Medicine, 19, 743-746.

8. Chikly BJ. (2005) 'Manual techniques addressing the lymphatic system: origins and development', The Journal of the American Osteopathic Association, 105, 457-464.

9. Crommert ME, Lacourpaille L, Heales LJ, Tucker K, Hug F. (2015) 'Muscle induces an immediate, albeit short-term, reduction in muscle stiffness', Scandinavian Journal of Medicine and Sports, 25, 490-496.

10. Gode RK. (1955) 'History of the practice of massage in Ancient and Medieval India between c. B.C. 1000 and A.D. 1900', Annals of the Bhandarkar Oriental Research Institute, 36, 85-113.

11. Hinds T, Mcewan I, Perkes J, Dawson E, Ball D, George K. (2004) 'Effects of massage on limb and skin blood flow after quadriceps exercise', Medicine and Science in Sports and Exercise, 36, 1308-1313.

12. Iorio S, Marinozzi S, Gazzaniga V. (2018) 'Healing bodies:the ancient origins of massages and Roman practices', Medicana Historica, 2, 58-62.

13. Kong PW, Chua YH, Kawabata M, Burns SF, Cai C. (2018) 'Effect of post-exercise massage on passive muscle stiffness measured using myotonometry-A double-blind study' Journal of Sports Science and Medicine, 17, 599-606.

14. Moosavi J. (2009) 'The place of Avicenna in the history of medicine', Avicenna Journal of Medical Biotechnology, 1, 3-8. 
15. Mori H, Ohsawa H, Tanaka TH, Taniwaki E, Leisman G, Nishijo K. (2004) 'Effect of massage on blood flow and muscle fatique following isometric lumbar exercise', Medical Science Monitor, 10, 173-178.

16. Moyer CA, Rounds J, Hannum JW. (2004) 'A meta-analysis of massage therapy research', Psychological Bulltein, 130, 3-18.

17. Nomikos NN, Nomikos GN, Kores DS. (2010) 'The use of deep friction massage with olive oil as a means of prevention and treatment of sports injuries in ancient times', Archives of Medical Science, 6, 642-645.

18. O'Keefe A. (2006) The official guide to body massage. London: Thomson Learning, 15.

19. Paulissian R. (1993) 'Dental Care in Ancient Assyria and Babylonia', Journal of Assyrian Academic Studies, 3-51.

20. Prioreschi P. (1998) A history of medicine: Roman medicine. Omaha: Horatius Press, 449.

21. Ryan AJ. (1984) 'Exercise and health: lessons from the past' In: Eckert HM, Montoye HJ, Eds, Exercise and health: the academy papers, Minnesota: Human kinetics publishers, 3-13.

22. Steinhorn DM, Din J, Johnson A. (2017) 'Healing, spirituality and integrative medicine' Annals of Palliative Medicine, 6, 237-247.

23. Thomson D, Gupta A, Arundell J, Crosbie J. (2015) 'Deep soft tissue massage applied to healthy calf muscle has no effect on passive mechanical properties: a randomized single-blind, cross-over study', BMC Sport Science, Medicine and Rehabilitation, 7, 21.

24. Tiidus PM, Shoemaker K. (1995) 'Effleurage massage, muscle blood flow and long-term post-exercise strength recovery', International Journal of Sports Medicine, 16, 478-483.

25. Tipton CM. (2014) 'The history of "Exercise Is Medicine" in ancient civilizations', Advances in Physiology Education, 38, 109-117.

26. Weerapong P, Hume PA, Kolt GS. (2005) 'The mechanisms of massage and effects on performance, muscle recovery and injury prevention", Sports Medicine, 35, 235-256.

27. Winkelman M. (2002) 'Shamanism as Neurotheology and Evolutionary Psychology', American Behavioral Scientist, 45, 1873-1885. 


\section{SAŽETAK}

Masaža je manipulacija tjelesnih tkiva pomoću tehnika kao što su trljanje, gnječenje, pritiskanje $i$ valjanje kako bi se održalo zdravlje. To je jedna od najstarijih i najprirodnijih ljekovitih primjena u ljudskoj povijesti. Avicena (980. - I037.) zauzeo je važno mjesto u svijetu medicine svojim najvažnijim djelom Kanon medicine, poznatim kao sveta knjiga medicine u zemljama zapadnog svijeta. U knjizi su definirane vrste masaža. To su čvrsto trljanje koje priprema tijelo, meko trljanje koje opušta tijelo, ponavljajuće trljanje koje smanjuje količinu masnih stanica u tijelu, umjereno čvrsto trljanje koje pomaže tijelu, grubo trljanje koje ubrzano dovodi krv do površine tijela, blago trljanje koje povećava protok krvi u području na kojem se primjenjuje, pripremno trljanje koje priprema tijelo prije vježbanja $i$ obnavljajuće trljanje koje se primjenjuje nakon vježbanja, a ublažava iscrpljenost. Može se vidjeti da je Avicena, čiji rad pokazuje utjecaj grčkih i rimskih liječnika, bio pod snažnim utjecajem Hipokrata $i$ Galena. Vidljivo je da su tehnike masaže i mehanizmi djelovanja, koje je Avicena definirao prije otprilike tisuću godina, uvelike pridonijeli razvoju masaže tijekom povijesti.

Ključne riječi: Avicena; Kanon medicine; masaža 